Tropical Journal of Pharmaceutical Research February 2017; 16 (2): 279-286

ISSN: $1596-5996$ (print); 1596-9827 (electronic)

(C) Pharmacotherapy Group, Faculty of Pharmacy, University of Benin, Benin City, 300001 Nigeria.

All rights reserved.

Available online at http://www.tjpr.org

Original Research Article

http://dx.doi.org/10.4314/tjpr.v16i2.4

\title{
Baicalein and U0126 suppress bladder cancer proliferation via MAPK signaling pathway
}

\author{
Xiaoping Tang ${ }^{1}$, Jiexiang Chen ${ }^{2}$, Xiaolan $\mathrm{Yu}^{3}$, Li Tang ${ }^{1}$, Yan $\mathrm{Li}^{1}$ and Jiyi Xia ${ }^{1,4 *}$ \\ ${ }^{1}$ Experimental Medicine Center, ${ }^{2}$ Department of Urology, The Affiliated Hospital of SouthWest Medical University, ${ }^{3}$ Department \\ of Obstetrics and Gynecology, The Affiliated TCM Hospital, ${ }^{4}$ The school of Medical Information and Engineering, SouthWest \\ Medical University, Luzhou, Sichuan, PR, China
}

*For correspondence: Email: xiajiyi0615@163.com; Tel/Fax: +86-0830-3161837

Received: 19 October 2016

Revised accepted: 16 January 2017

\begin{abstract}
Purpose: To investigate baicalein and 1,4-diamino-2,3-dicyano-1,4-bis[2-aminophenylthio] butadiene (U0126)effects on human bladder cell line T24 proliferation and related mechanisms.

Methods: Twenty micromoles of baicalein or $10 \mu M$ U0126 were incubated with T24 cells. Cell viability was tested by CCK8 assay. Cell cycle was evaluated by flow cytometry while cell apoptosis was detected by Annexin VIPI and TUNEL assay. MAPK signaling pathway was evaluated by real time polymerase chain reaction (RT-PCR) and western blot.

Results: Baicalein and U0126 suppressed bladder cancer cell T24 proliferation by blocking cell cycle in G0 G1 phase. TUNEL and Annexin V/PI detection showed both baicalein and U0126 induced T24 cell apoptosis. Baicalein and U0126 significantly down-regulated MAPK signaling pathway related molecule activity in both mRNA and protein levels $(p<0.05)$.

Conclusion: Baicalein and U0126 restrain bladder cancer cell proliferation and promote cell apoptosis by affecting MAPK signaling pathway. Thus, they have potentials for use in the treatment of bladder cancer.
\end{abstract}

Keywords: Bladder cancer, Baicalein, 1,4-diamino-2,3-dicyano-1,4-bis[2-aminophenylthio] butadiene, MAPK signal pathway, Apoptosis

Tropical Journal of Pharmaceutical Research is indexed by Science Citation Index (SciSearch), Scopus, International Pharmaceutical Abstract, Chemical Abstracts, Embase, Index Copernicus, EBSCO, African Index Medicus, JournalSeek, Journal Citation Reports/Science Edition, Directory of Open Access Journals (DOAJ), African Journal Online, Bioline International, Open-J-Gate and Pharmacy Abstracts

\section{INTRODUCTION}

Bladder cancer is a common malignant cancer in the urinary system. Bladder epithelial tumor accounts for 95 98\%, of which transitional cell carcinoma accounts for $90 \%$, and non-epithelial tumor including phosphorus epithelial carcinoma and adenocarcinoma occupies $2-5 \%[1,2]$. Bladder cancer occurrence and development are multi-factorial, polygenic, and multi-step processes, which is closely related to cell proliferation and apoptosis. A variety of growth factors, oncoproteins, and their interactions play important roles in cancer proliferation and apoptosis. Their imbalance is the basis of bladder cancer oncogenesis $[3,4]$. Inducing cell apoptosis is an important strategy for bladder cancer treatment [5].

Mitogen-activated protein kinase (MAPK), including ERK1/2, JNK and P38, is closely related to cell proliferation, differentiation, and carcinogenesis [6]. Extracellular signal-regulated kinase (ERK) is one of the most important classical kinase signaling pathways of MAPK family. It can be activated by phosphorylation, and participates in cell proliferation, differentiation, and apoptosis by regulating a variety of oncogenes. ERK1/2 level has been 
found significantly overexpressed in breast, colon and lung cancers. JNK signaling pathway could be triggered by multiple factors, including cytokines, heat shock, growth factors, osmotic pressure, stress, ionizing radiation, and oxidative damage. Activated JNK can phosphorylate cJun, ATF-2, and Elk, which regulate cancer cell proliferation, differentiation, and apoptosis. P38 can regulate multiple biological processes, such as inflammation, apoptosis, and cell cycle. At present, it is found that P38 has four types of isomers, including P38 $\alpha, P 38 \beta, P 38 \gamma$, and P38ס. Different subtypes distributes in different tissues. After activation by MKK3 or MKK6, P38 can phosphorylate ATF and Elk-1 to regulate cell proliferation, carcinogenesis, or apoptosis [7].

Because of its high incidence and fatality, antibladder cancer drugs investigation is full of challenge. Currently, the commonly used chemotherapy drugs in the clinic include methotrexate, doxorubicin, cisplatin, and fluorouracil. They have certain curative effect but the side effect is high. Therefore, new drug research is of great clinical significance [8]. Baicalein is a type of Chinese Traditional Medicine that is often used in the treatment of cerebrovascular disease after paralysis. It also can be adopted in cancer treatment, whereas its curative effect in bladder cancer is still poorly understood [9]. U0126 is a highly specific MEK1/2 inhibitor, which can reduce MAPK phosphorylation to inhibit cancer cell proliferation [10]. This study mainly explored baicalein and U0126 combined therapy to affect human bladder cancer T24 cell proliferation and apoptosis.

\section{EXPERIMENTAL}

\section{Materials}

Human bladder cancer T24 cells were obtained from Department Of Urinary Surgery, Wuhan Tongji Hospital. The cells were maintained in McCoy's 5A media containing $10 \%$ fetal calf serum, $100 \mathrm{~g} / \mathrm{mL}$ streptomycin, and $100 \mathrm{U} / \mathrm{mL}$ penicillin, and cultured at $37{ }^{\circ} \mathrm{C}$ and $5 \% \mathrm{CO}_{2}$. The cells were digested by $0.25 \%$ trypsin for passage. Baicalein purchased from Biopurify. U0126 was bought from Haoran Biotech Co, Ltd.

\section{CCK8 assay}

T24 cells in suspension were seeded in a 96-well plate. Different concentrations of baicalein or U0126 were added to the cells for $4 \mathrm{~h}$ in triplicate. Thereafter, $10 \mu \mathrm{L} \mathrm{CCK8}$ reagent was inserted to the well and incubated for $4 \mathrm{~h}$ to form formazan. The samples were measured at 450 -
$490 \mathrm{~nm}$ on a microplate reader (Thermo Electron).

\section{Cell cycle detection}

T24 cells were seeded in 12-well plate and stimulated by baicalein or U0126. After collection and washing twice with PBS, the cells were moved to $1 \mathrm{~mL} 70 \%$ precooled ethanol at $4{ }^{\circ} \mathrm{C}$ overnight. Then the cells were washed with PBS and interfered by $100 \mathrm{mg} / \mathrm{L}$ RNase at $37^{\circ} \mathrm{C}$ for $30 \mathrm{~min}$. After incubated with $50 \mathrm{mg} / \mathrm{L} \mathrm{PI}$ at $4{ }^{\circ} \mathrm{C}$ avoid of light for $30 \mathrm{~min}$, the cells were detected on flow cytometry with excitation wavelength at $488 \mathrm{~nm}$. The primary result was analyzed with a cell cycle matching software to record hypodiploid peak. All the experiments were repeated for at least three times.

\section{TUNEL assay}

T24 cells were washed with PBS twice after treatment and then fixed in $4 \%$ PFA at room temperature for $10 \mathrm{~min}$. Then the cells were treated with $3 \%$ hydrogen peroxide for $10 \mathrm{~min}$ to inhibit endogenous catalase. After incubation with protease at room temperature for $30 \mathrm{~min}$, the cells were washed with PBS twice. Next, the cells were incubated with $50 \mu \mathrm{L}$ TUNEL at room temperature for $60 \mathrm{~min}$. and observed under microscope after washing with PBS three times to analyze the result.

\section{Annexin V/PI assay}

After treating with $20 \mu \mathrm{M}$ baicalein or $10 \mu \mathrm{M}$ U0126 for 24 h, T24 cells were collected and washed with PBS twice. Then the cells were resuspended in $400 \mu \mathrm{L} 1 \times$ binding buffer and treated by $5 \mu \mathrm{L}$ Annexin V-FITC in the dark for $15 \mathrm{~min}$. Then the cells were added with $10 \mu \mathrm{L} \mathrm{PI}$ and incubated avoid of light for $5 \mathrm{~min}$. The cells were then tested for early and late apoptosis with a flow cytometry. The results were analyzed with Cell Quest software. Each group was repeated three times.

\section{Real time PCR}

Total RNA was extracted using Trizol and reverse transcribed to cDNA using K1622 kit (ThermoFermentas). The primers used were designed by Primer 6.0. Real time PCR was applied to test target gene expression. Reaction condition: $55^{\circ} \mathrm{C}$ for $1 \mathrm{~min}$, followed by 40 cycles of $94{ }^{\circ} \mathrm{C}$ for $30 \mathrm{~s}, 55^{\circ} \mathrm{C}$ for $30 \mathrm{~s}$, and $72{ }^{\circ} \mathrm{C}$ for 45 s. GAPDH was selected as the housekeeping gene. $2^{-}{ }^{\mathrm{Ct}}$ was applied to calculate relative expression level. The primers sequences were listed in Table 1. 
Table 1: Primer sequences

\begin{tabular}{lll}
\hline Gene name & Primer & $\mathbf{5}^{\prime} \mathbf{- 3}^{\prime}$ \\
\hline ERK1/2 & Sense & AATCACACGGTAGACACTGAAATGCC \\
& Anti-sense & CATCATCCCATCTAAAATGTCCCCTG \\
Bax & Sense & CCCGAGAGGTCTTTTTCCGAG \\
& Anti-sense & CCAGCCCATGATGGTTCTGAT \\
Bcl-2 & Sense & GGTGGGGTCATGTGTGTGG \\
& Anti-sense & CGGTTCAGGTACTCAGTCATCC \\
P38 & Sense & CCCGAGCGTTACCAGAACC \\
& Anti-sense & TCGCATGAATGATGGACTGAAAT \\
GAPDH & Sense & GCACCGTCAAGGC \\
& Anti-sense & TGGTGAAGACGCCAGTGGA \\
\hline
\end{tabular}

\section{Western blot}

T24 cells were placed on ice for $20 \mathrm{~min}$ after which protease inhibitor was added and lysed to extract protein. After centrifugation at 12,000 $\mathrm{r} / \mathrm{min}$, the supernatant was taken into to a new eppendorf tube and the protein concentration was determined with BCA reagent. A total of 20 $\mu \mathrm{g}$ protein was separated by $10 \%$ SDS-PAGE and transferred to PVDF membrane. After blocking with $5 \%$ skimmed milk for $1.5 \mathrm{~h}$, the membrane was incubated with primary antibody for $2 \mathrm{~h}$. Then the membrane was incubated with secondary antibody for $30 \mathrm{~min}$ and washed with PBST. The membrane was developed with DAB and scanned using ECL. All experiments were repeated three times.

\section{Statistical analysis}

All the data are depicted as mean \pm standard deviation (SD) and were analyzed with SPSS19.0 software. Data comparison was performed using one-way ANOVA or t-test. $P<$ 0.05 was considered as statistically different.

\section{RESULTS}

\section{Baicalein and U0126 suppressed proliferation by blocking cell cycle}

To explore the restraining effect of baicalein and U0126 on T24 cells, we used different concentrations of baicalein $(1,2,5,10,20,50$, $100,200$ and $300 \mu \mathrm{M})$ or $\operatorname{U0126}(1,2,5,10,20$ and $30 \mu \mathrm{M})$ to treat T24 cells for $24 \mathrm{~h}$. CCK8 results demonstrated that T24 cell viability was significantly reduced by baicalein or U0126 with dose dependence $(p<0.05)$ (Figure 1A). Since MAPK signaling pathway can regulate cell cycle, we aimed to clarify if baicalein and U0126 impact on T24 cell cycle. We treated T24 cells with 20 $\mu \mathrm{M}$ baicalein or $20 \mu \mathrm{M}$ U0126 for $24 \mathrm{~h}$. Flow cytometry showed that compared with control, cell content increased in $\mathrm{G}_{0} \sim \mathrm{G}_{1}$ phase and reduced in $S$ phase (Figure $1 \mathrm{~B}$ ). U0126 addition markedly down-regulated cell content in $S$ phase compared with the single baicalein group (Figure 1B). We also tested for cyclin D1 mRNA expression in T24 cells treated with baicalein or U0126. Real time-PCR illustrated that cyclin D1 mRNA level declined after treatment with $20 \mu \mathrm{M}$ baicalein for $24 \mathrm{~h}$. U0126 further down-regulated cyclin D1 expression ( $p<0.05$, Figure 1C).

\section{Baicalein and U0126 induced T24 cell apoptosis}

To explore if baicalein and U0126 impact on T24 cell apoptosis, we treated T24 cells with $20 \mu \mathrm{M}$ baicaleina and $20 \mu \mathrm{M}$ U0126. TUNEL assay showed that both baicalein and U0126 caused T24 cell apoptosis synergistically (Figure 2A). To further examine the specific phase of apoptosis caused by baicalein and U0126, annexin V/PI staining showed that baicalein and U0126 increased both early and late phases of apoptosis with synergistic effect (Figure 2B).

Baicalein and U0126 affected MAPK signaling pathway and Bax/Bcl-2 ratio at mRNA level

Since previous research reported that baicalein can regulate MAPK signaling pathway, we tested the effect of baicalein and U0126 on MAPK signaling pathway in T24 cells at the mRNA level. Real time PCR results showed that baicalein reduced ERK1/2 and P38 levels in T24 cells. Moreover, it significantly upregulated proapoptotic factor Bax mRNA expression and downregulated apoptosis suppression gene Bcl-2 mRNA level, resulting in $\mathrm{Bax} / \mathrm{Bcl}-2$ ratio elevation $(p<0.05$, Figure 3$)$.

\section{Baicalein and U0126 reduced MAPK signaling pathway and increased $\mathrm{Bax} / \mathrm{Bcl}-2$ ratio at protein level}

Furthermore, the impact of baicalein and U0126 on MAPK signaling pathway and apoptosis related protein expression. Western blot revealed that ERK1/2 phosphorylation and P38 levels were markedly reduced in T24 cells treated with baicalein. Bax and Bcl-2 protein also showed 
similar trend with mRNA expression. Baicalein together with U0126 suppressed MAPK signaling pathway related proteins expression more compared with single baicalein treatment (Figure 4).

\section{DISCUSSION}

Bladder cancer is one of the main causes of morbidity and mortality in urinary system, with 7 $\%$ morbidity and $3 \%$ mortality among cancers $[11,12]$. Although localized bladder carcinomas can be treated by surgical resection, however, its recurrence and progression rates are still high. More in-depth research is needed for bladder cancer to clarify the underlying molecular mechanisms of its tumorigenesis. There is extensive information on bladder cancer at the genetic and molecular levels, however, their limited value compelled researchers to search for new molecular parameters for bladder cancer treatment.

Baicalein is the active component of Chinese traditional medicine radix scutellariae with multiple effects, such as antibiotic, antivirus, antiinflammation. It has a variety of effects and can decrease inflammation, has antibacterial, antiviral, liver protection, diuresis, and anticancer properties. At present, it is mainly used for acute or chronic inflammation, while its curative effect in bladder cancer is still poorly understood. Some researchers reported that baicalein can inhibit cancer formation and induce cancer cells apoptosis, which is attractive with good prospect [13]. U0126 is an efficient selective inhibitor of MAPK kinase MEK1 and MEK2. It presents weak or no inhibitory effect on other kinases, such as PKC, Raf, and Cdk4. U0126 can suppress activated or inactivated MEK1/2 simultaneously, while PD98059 can only inhibit inactivated MEK1/2. U0126 suppresses MEK1/2 by non-competitive inhibition, as it not only antagonizes the transcriptional activity of AP-1, but also prevents the activation of MAPK p42/p44 encoded by erk2 and erk1 gene. Since MAPKp42/p44 participates in signaling cascade activated by LPS or other lipid through TLRs, U0126 could be used for numerous cancer therapy [14].
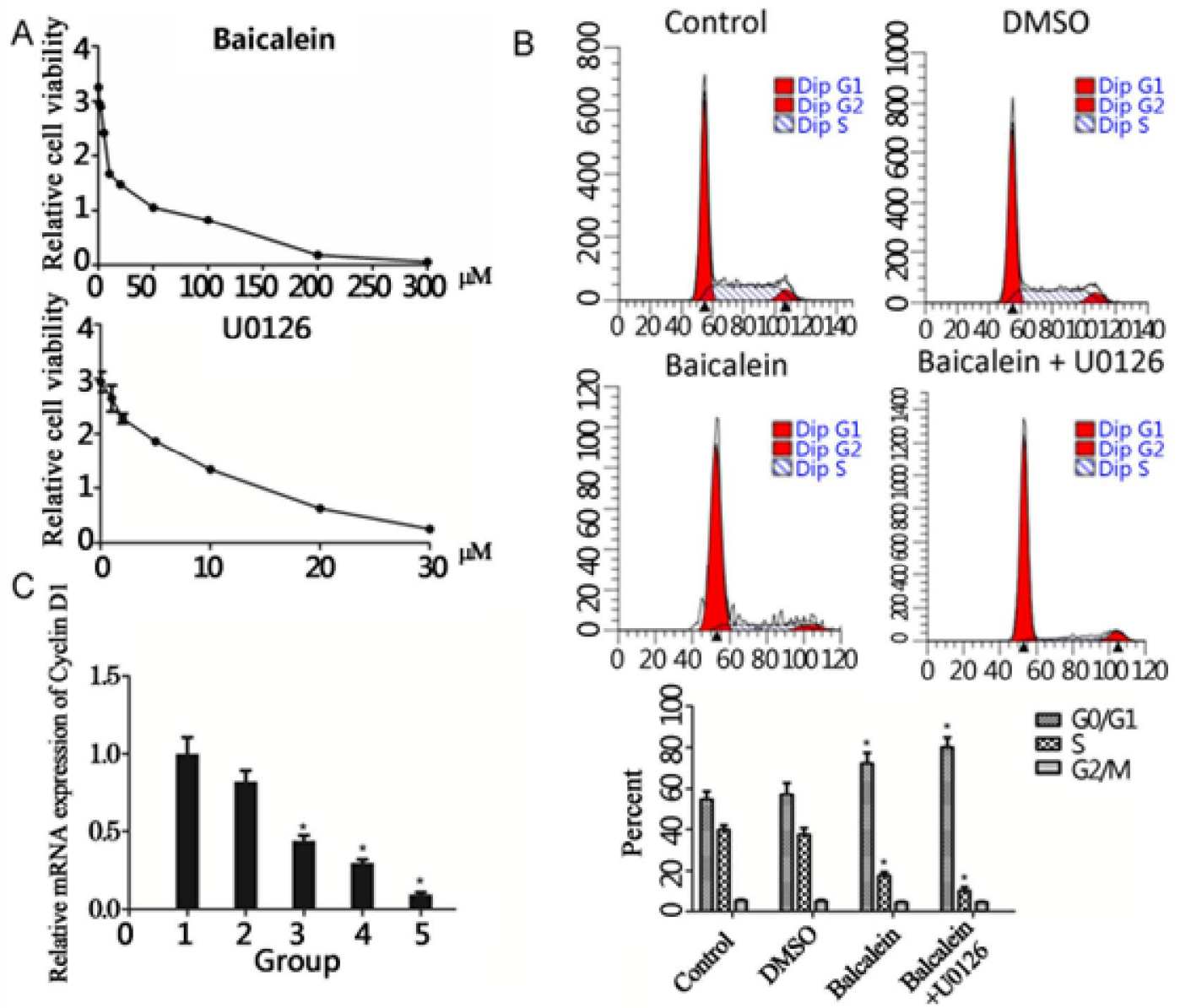

Figure 1: Baicalein and U0126 suppressed T24 cell proliferation by restraining cell cycle. (A) T24 cell viability detected by CCK-8. (B) T24 cell cycle tested by flow cytometry. (C) cyclin D1 mRNA expression determined by real time PCR. Note: 1 = control; 2 = control + DMSO; 3 = baicalein $20 \mu \mathrm{M} ; 4=$ U0126 $20 \mu \mathrm{M} ; 5$ = baicalein 20 $\mathrm{Mm}+\mathrm{U} 012620 \mu \mathrm{M} ;{ }^{*} p<0.05$, compared with control 
A



$\mathrm{B}$

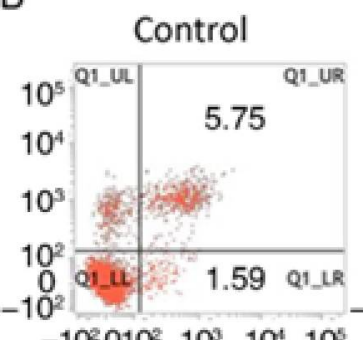

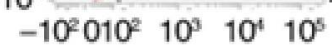

Baicalein
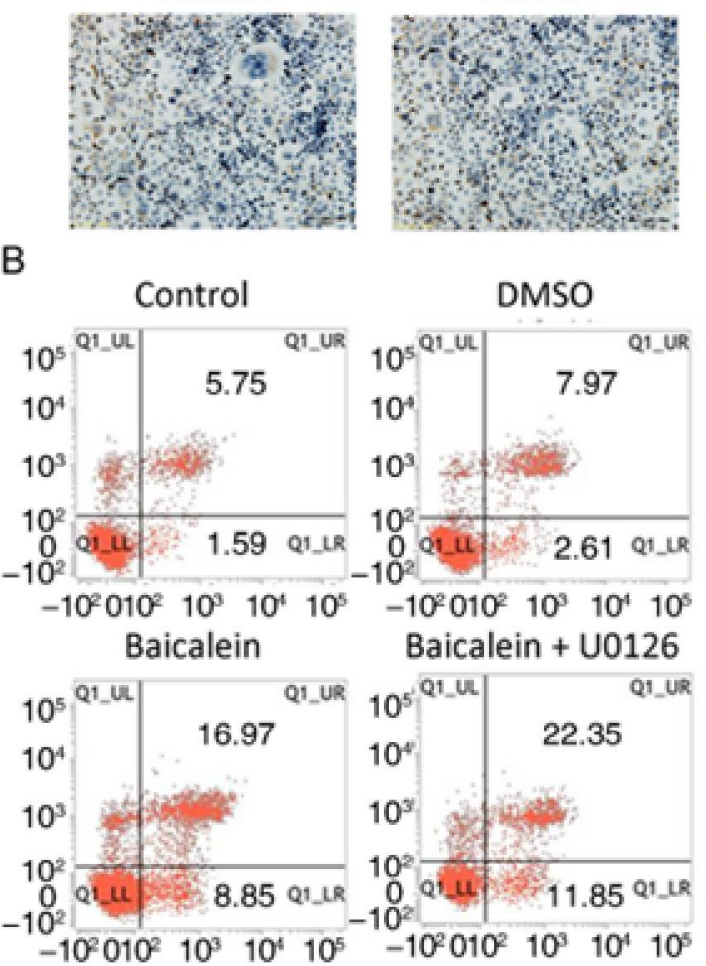

DMSO

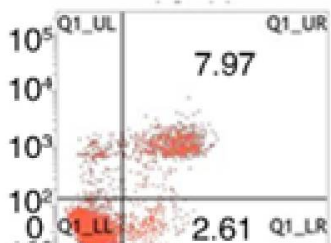

${ }_{10}^{\circ}$ QLu 2.61 Q1_L

$\begin{array}{llll}-10^{2} 010^{2} & 10^{9} & 10^{4} & 10^{5}\end{array}$

Baicalein + U0126
Baicalein

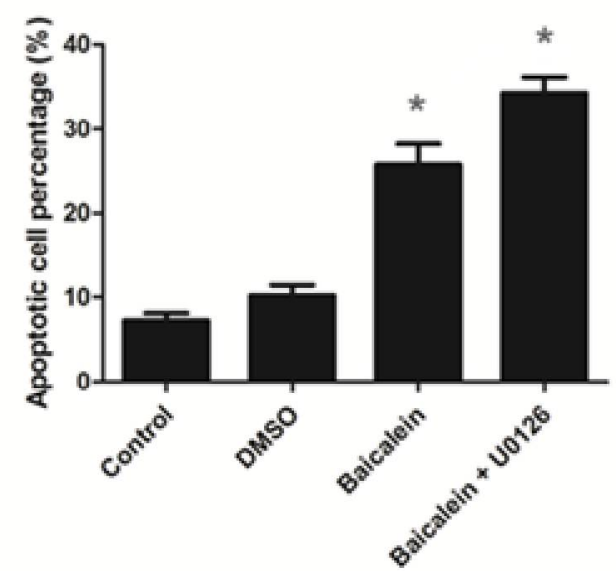

Figure 2: Baicalein induced T24 cell apoptosis. (A) T24 cell apoptosis detected by TUNEL. (B), T24 cell apoptosis tested by Annexin V/PI double staining; ${ }^{*} p<0.05$, compared with control
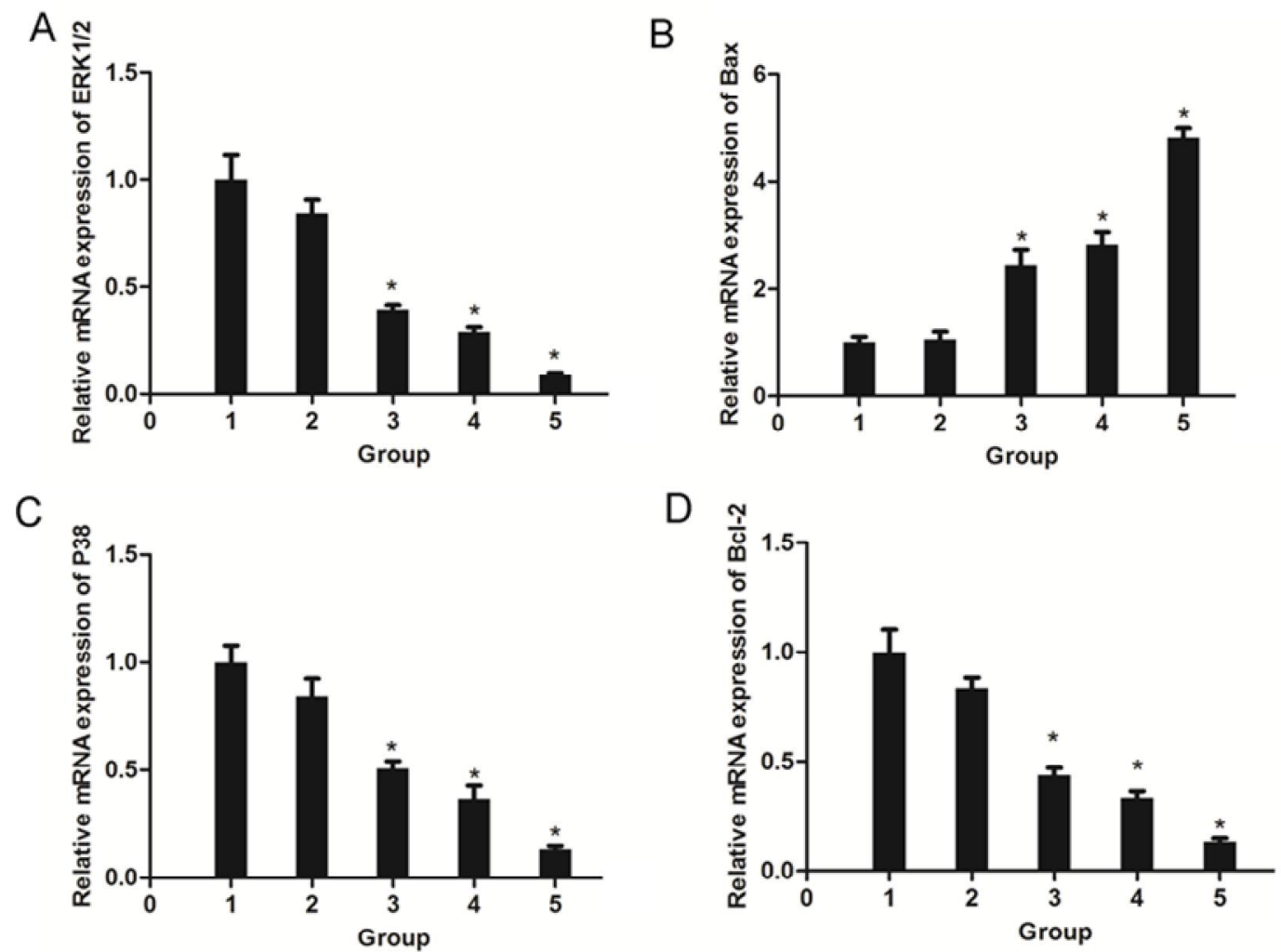

Figure 3: Baicalein and U0126 affected MAPK signaling pathway and Bax/Bcl-2 ratio at the mRNA level. Note: 1 = control; 2 = control + DMSO; 3 = baicalein $20 \mu \mathrm{M} ; 4$ = U0126 $20 \mu \mathrm{M} ; 5$ = baicalein $20 \mathrm{Mm}+\mathrm{U} 012620 \mu \mathrm{M}$; (A) Relative mRNA expression of ERK1/2; (B) Relative mRNA expression of Bax; (C) Relative mRNA expression of p38; (D) Relative mRNA expression of Bcl-2; ${ }^{*} p<0.05$, compared with control 

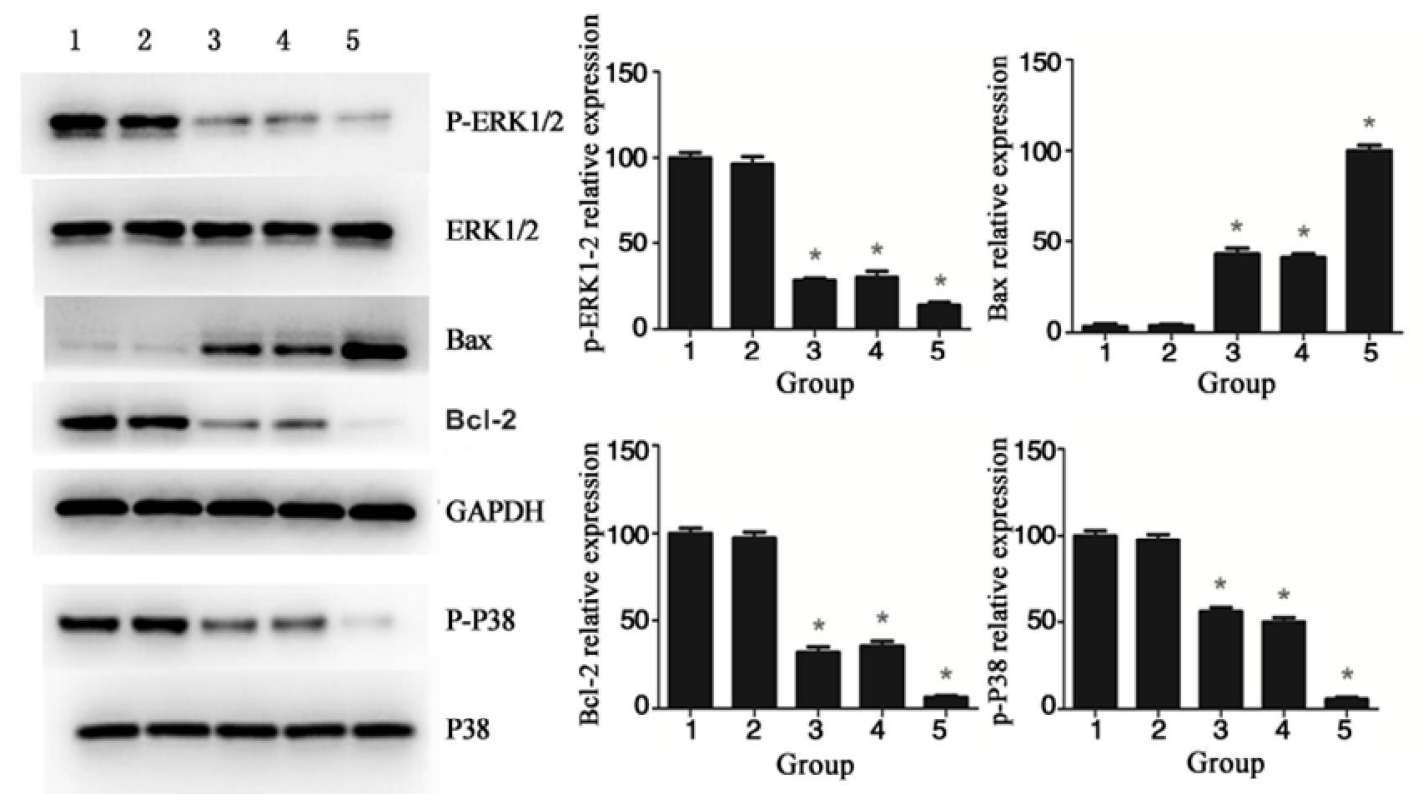

Figure 4: Baicalein and U0126 reduced MAPK signaling pathway and increased Bax/Bcl-2 ratio at the protein level. Note: 1 = control; 2 = control + DMSO; 3 = baicalein $20 \mu \mathrm{M} ; 4=$ U0126 $20 \mu \mathrm{M} ; 5$ = baicalein $20 \mathrm{Mm}+$ U0126 $20 \mu \mathrm{M}$; ${ }^{*} p<0.05$, compared with control

ERK1/2/MAPK pathway plays a critical role in bladder cancer occurrence and development. Its abnormal activation leads cancer cells to lose apoptosis and differentiation abilities, thus promoting cancer cells malignant transformation and abnormal proliferation [15]. Therefore, blocking ERK1/2/MAPK signaling pathway is of great importance for the treatment of bladder cancer. ERK1/2/MAPK signal pathway has three key molecules, namely Ras, Raf, and MEK. Ras is currently the most conservative cancer gene, including K-Ras, H-Ras, N-Ras, R-Ras, and TC21. Raf is a serine/threonine protein kinase, which contains three main types in humans as CRaf, A-Raf, and B-Raf. MEK (ERK kinase) is an uncommon dual specific protein kinase. It is not only Tyr protein kinase, but also Ser/Thr protein kinase, including MEK1 and MEK2. The kinases that participate in ERK signaling pathway at different levels include C-Raf and MEK1/2 [16]. Inactivating these molecules as therapeutic targets may achieve the goal of bladder cancer treatment. This study applied baicalein and U0126 to inhibit human bladder cancer cell line T24, and found that ERK1/2 expression and phosphorylation level significantly decreased. It suggested that blocking ERK1/2 signaling pathway can effectively inhibit cancer cell proliferation and induce apoptosis.

ERK signaling pathway is important for regulating cell cycle by promoting cells from $\mathrm{G} 1$ phase to $\mathrm{S}$ phase [17]. Our results showed that baicalein blocked T24 cells in G0 G1 phase. Moreover, U0126 also reduced cell proportion in S phase. Cyclin D1 level was also reduced after baicalein and U0126 treatment, suggesting that both baicalein and U0126 can inhibit bladder cancer proliferation through blocking cell cycle.

P38 is another type of MAPK signaling pathway, which is closely associated with cell proliferation, differentiation, apoptosis, and carcinogenesis processes [18]. Glandular cystitis is a kind of disease characterized by hyperplasia combined with metaplasia, while the occurrence of transitional cell carcinoma is also the result of abnormal cell proliferation. Since P38 expression and phosphorylation levels declined in patients with bladder cancer, p38 signaling pathways plays a key role in the occurrence and development of bladder cancer [19]. P38 expression and phosphorylation levels was found significantly decreased in T24 cells stimulated by baicalein and U0126.

$\mathrm{Bax}$ and $\mathrm{Bcl}-2$ are the two most important members of Bcl-2 family, which mainly distribute in the mitochondria, endothelium, and nuclear membrane. Bcl-2 can inhibit a cell under goes apoptosis through inducing resistance to various stimuli. Bax can antagonize Bcl-2 function by forming heterodimer. The ratio of $\mathrm{Bax}$ and $\mathrm{Bcl}-2$ determines whether cell apoptosis or not $[20,21]$. Bcl-2 does not express in normal bladder tissue, whereas its expression rate reached $60 \%$ in bladder cancer and increased following pathological upgrading [22,23]. Our results showed that both baicalein and U0126 induced cell apoptosis. Furthermore, they decreased Bcl2 expression and enhanced Bax level. All of 
these results suggested that baicalein and U0126 can cause bladder cancer cell apoptosis.

\section{CONCLUSION}

Taken together, baicalein and U0126 can inhibit T24 cell proliferation through regulating MAPK signaling pathway. Their combination increased the inhibition of bladder cancer cell proliferation and facilitated cell apoptosis, providing theoretical basis for their use in bladder cancer treatment.

\section{DECLARATIONS}

\section{Acknowledgement}

This work was supported by The Fund of Science and Technology Department of Sichuan Province (no. 14JC01383-LH53 and 14JC01353LH67), The Fund of Science and Technology Department of Luzhou City (no. 2014-S-44) and The Mutual Fund of Science and Technology Department of Sichuan Province (no. 2015sx0002).

\section{Conflict of Interest}

No conflict of interest associated with this work.

\section{Contribution of Authors}

The authors declare that this work was done by the authors named in this article and all liabilities pertaining to claims relating to the content of this article will be borne by them.

\section{Open Access}

This is an Open Access article that uses a funding model which does not charge readers or their institutions for access and distributed under the terms of the Creative Commons Attribution License (http://creativecommons.org/licenses/by /4.0) and the Budapest Open Access Initiative (http://www.budapestopenaccessinitiative.org/rea d), which permit unrestricted use, distribution, and reproduction in any medium, provided the original work is properly credited.

\section{REFERENCES}

1. Bertz S, Hartmann A, Knuchel-Clarke R, Gaisa NT. Specific types of bladder cancer. Pathologe 2016; 37 : 40-51.

2. Wirtz RM, Fritz $V$, Stohr $R$, Hartmann A. Molecular classification of bladder cancer : Possible similarities to breast cancer. Pathologe 2016; 37: 52-60.
3. Famularo $G$, Stasolla $A$, Gasbarrone $L$. Pachydermoperiostosis and bladder cancer. Dermatol Online J 2015; 21.

4. Thompson DB, Siref LE, Feloney MP, Hauke RJ, Agrawal $D K$. Immunological basis in the pathogenesis and treatment of bladder cancer. Expert Rev Clin Immunol 2015; 11: 265-279.

5. Zhang ZW, Xiao J, Luo W, Wang BH, Chen JM. Caffeine Suppresses Apoptosis of Bladder Cancer RT4 Cells in Response to lonizing Radiation by Inhibiting Ataxia Telangiectasia Mutated-Chk2-p53 Axis. Chin Med J (Engl) 2015; 128: 2938-2945.

6. Finch AR, Caunt CJ, Perrett RM, Tsaneva-Atanasova K, McArdle CA. Dual specificity phosphatases 10 and 16 are positive regulators of EGF-stimulated ERK activity: indirect regulation of ERK signals by JNK/p38 selective MAPK phosphatases. Cell Signal 2012; 24: 1002-1011.

7. Rusyn EV, Reynolds ER, Shao H, Grana TM, Chan TO, Andres $D A$, Cox $A D$. Rit, a non-lipid-modified Rasrelated protein, transforms NIH3T3 cells without activating the ERK, JNK, p38 MAPK or PI3K/Akt pathways. Oncogene 2000; 19: 4685-4694.

8. Xie H, Li C, Dang Q, Chang LS, Li L. Infiltrating mast cells increase prostate cancer chemotherapy and radiotherapy resistances via modulation of p38/p53/p21 and ATM signals. Oncotarget 2016; 7: 1341-1353.

9. Guo Z, Hu X, Xing Z, Xing R, Lv R, Cheng X, Su J, Zhou $Z$, $X u Z$, Nilsson S, Liu Z. Baicalein inhibits prostate cancer cell growth and metastasis via the caveolin1/AKT/mTOR pathway. Mol Cell Biochem 2015; 406 : 111-119.

10. Rose HM, Stuiver M, Thongwichian R, Theillet FX, Feller $S M$, Selenko P. Quantitative NMR analysis of Erk activity and inhibition by $U 0126$ in a panel of patientderived colorectal cancer cell lines. Biochim Biophys Acta 2013; 1834: 1396-1401.

11. Burger M, Catto JW, Dalbagni G, Grossman HB, Herr $H$, Karakiewicz $P$, Kassouf W, Kiemeney LA, La Vecchia $C$, Shariat S, Lotan Y. Epidemiology and risk factors of urothelial bladder cancer. Eur Urol 2013; 63: 234-241.

12. Siegel RL, Miller KD, Jemal A. Cancer statistics, 2015. CA Cancer J Clin 2015; 65: 5-29.

13. Aryal P, Kim K, Park PH, Ham S, Cho J, Song K. Baicalein induces autophagic cell death through AMPK/ULK1 activation and downregulation of mTORC1 complex components in human cancer cells. FEBS $J$ 2014; 281: 4644-4658.

14. Lodi A, Woods SM, Ronen SM. Treatment with the MEK inhibitor U0126 induces decreased hyperpolarized pyruvate to lactate conversion in breast, but not prostate, cancer cells. NMR Biomed 2013; 26: 299-306.

15. Park SL, Kim WJ, Moon SK. p21WAF1 mediates the IL15-induced migration and invasion of human bladder cancer 5637 cells via the ERK1/2/NF-kappaB/MMP-9 pathway. Int Immunopharmacol 2014; 22: 59-65.

16. D'Ambrosio SM, Han C, Pan L, Kinghorn AD, Ding $H$. Aliphatic acetogenin constituents of avocado fruits inhibit human oral cancer cell proliferation by targeting

Trop J Pharm Res, February 2017; 16(2): 285 
the EGFR/RAS/RAF/MEK/ERK1/2 pathway. Biochem Biophys Res Commun 2011; 409: 465-469.

17. Liu Z, Ren L, Liu C, Xia T, Zha X, Wang S. Phenformin Induces Cell Cycle Change, Apoptosis, and Mesenchymal-Epithelial Transition and Regulates the AMPK/mTOR/p70s6k and MAPK/ERK Pathways in Breast Cancer Cells. PLoS One 2015; 10: e0131207.

18. Al-Azayzih A, Gao F, Goc A, Somanath PR. TGFbeta1 induces apoptosis in invasive prostate cancer and bladder cancer cells via Akt-independent, p38 MAPK and JNK/SAPK-mediated activation of caspases. Biochem Biophys Res Commun 2012; 427: 165-170.

19. Kumar B, Koul S, Petersen J, Khandrika L, Hwa JS, Meacham RB, Wilson S, Koul HK. p38 mitogenactivated protein kinase-driven MAPKAPK2 regulates invasion of bladder cancer by modulation of MMP-2 and MMP-9 activity. Cancer Res 2010; 70: 832-841.

20. Tjalma WA, Weyler JJ, Bogers JJ, Pollefliet C, Baay M, Goovaerts GC, Vermorken JB, van Dam PA, van Marck
$E A$, Buytaert PM. The importance of biological factors (bcl-2, bax, p53, PCNA, MI, HPV and angiogenesis) in invasive cervical cancer. Eur J Obstet Gynecol Reprod Biol 2001; 97: 223-230.

21. Zhao LW, Zhong XH, Yang SY, Zhang YZ, Yang NJ. Inotodiol inhabits proliferation and induces apoptosis through modulating expression of cyclinE, p27, bcl-2, and bax in human cervical cancer HeLa cells. Asian Pac J Cancer Prev 2014; 15: 3195-3199.

22. Kiss $B$, Skuginna $V$, Fleischmann $A$, Bell $R H$, Collins $C$, Thalmann GN, Seiler R. Bcl-2 predicts response to neoadjuvant chemotherapy and is overexpressed in lymph node metastases of urothelial cancer of the bladder. Urol Oncol 2015; 33: 166 e161-168.

23. Sakr SA, Mahran HA, Fahmy AM, El-Kholy MA, Meawad $M$. Expression of c-erb-B2 gene in bladder cancer of Egyptian patients and its correlation with $p 53$ and bcl-2. Biomed Pharmacother 2015; 76: 73-81. 